Jurnal Sulolipu : Media Komunikasi Sivitas Akademika dan Masyarakat

Vol. 21 No. 12021

e-issn: 2622-6960, p-issn : 0854-624X

\title{
HUBUNGAN SANITASI TOTAL BERBASIS MASYARAKAT (STBM) DENGAN UPAYA PENURUNAN ANGKA STUNTING PADA BALITA (STUDI LITERATUR)
}

Community Led Total Sanitation (CLTS) Relations With Efforts to Reduce Stunting Rates in Toddlers (Literature Study)

${ }^{1}$ Surni Opu, ${ }^{2}$ Hidayat, ${ }^{3}$ Ain Khaer

1,2,3 Jurusan Kesehatan Lingkungan Poltekkes Kemenkes Makassar

*)surniopu21@gmail.com, 082348383884

\begin{abstract}
Stunting is an obstacle to children's growth and development caused by chronic malnutrition, recurrent disease infections, and lack of psychosocial stimulation. Stunting starts from the womb and is only seen when a child is two years old or in the first 1000 days, where the child physically looks shorter than other children his age. The purpose of this study was to determine the relationship of Community Led Total Sanitation (CLTS) with efforts to reduce the number of stunting in infants. This type of research is a literature study with a descriptive approach that is collecting data in the form of secondary data obtained from the literature, books, and previous research results by examining the relationship between the independent variable and the dependent variable. The results showed that there was a relationship between community led total sanitation (clts) pillar l, open defecation (sbas) and efforts to reduce stunting in infants, there was a relations hip between community led total sanitation (clts) pillar II, washing hands with soap (ctps) with efforts to reduce stunting in toddlers, there is a relationship between community led total sanitation (clts) pillar III management of drinking water and household food (pamm-rt) with efforts to reduce stunting in toddlers. The conclusion of this study is that there is a relationship between community led total sanitation (clts) and efforts to reduce the number of stunting in children under five. Suggestions in this study are for the public to pay more attention and apply healthy lifestyles in the 5 pillars of CLTS as an effort to prevent and reduce stunting.
\end{abstract}

Keywords: Stunting, CLTS, SBABS, CTPS, and PAMM-RT

\section{ABSTRAK}

Stunting adalah hambatan tumbuh kembang anak yang disebabkan oleh kekurangan gizi secara kronis, infeksi penyakit yang berulang dan kurangnya stimulasi psikososial. Stunting terjadi mulai dari dalam kandungan dan baru terlihat saat anak berusia dua tahun atau masa 1000 hari pertama, dimana anak secara fisik terlihat lebih pendek daripada anak lain seumurnya. Tujuan dari penelitian ini adalah untuk mengetahui hubungan sanitasi total berbasis masyarakat (STBM) dengan upaya penurunan angka stunting pada balita berdasarkan hasil penelitian/jurnal dalam kurun waktu 2017- 2020. Adapun jenis penelitian ini adalah literature review. Sampel dalam penelitian ini adalah literature berupa artikel/jurnal yang memenuhi kriteria dan relevan dengan Perilaku dan pengetahuan tentang buang air besar sembarangan serta kejadia penyakit diare dengan kejadian stunting. Data yang dihasilkan dari hasil pengumpulan jurnal yang relevan kemudian dianalisa sesuai variabel dan disajikan dalam bentuk table. Hasil penelitian menunjukkan ada hubungan antara sanitasi total berbasis masyarakat (stbm) pilar I stop buang air besar sembarangan (sbas) dengan upaya penurunan angka stunting pada balita, ada hubungan antara sanitasi total berbasis masyarakat (stbm) pilar Il cuci tangan pakai sabun (ctps) dengan upaya penurunan angka stunting pada balita, ada hubungan antara sanitasi total berbasis masyarakat (stbm) pilar III pengelolaan air minum dan makanan rumah tangga (pamm-rt) dengan upaya penurunan angka stunting pada balita. Kesimpulan penelitian ini adalah ada hubungan antara sanitasi total berbasis masyarakat (stbm) dengan upaya penurunan angka stunting pada balita. Saran dalam penelitian ini adalah agar masyarakat lebih memperhatikan dan menerapkan pola hidup sehat dalam 5 pilar STBM sebagai suatu upaya pencegahan dan penurunan angka stunting.

Kata Kunci: Stunting, STBM, SBABS, CTPS, dan PAMM-RT

\section{Pendahuluan}

Sanitasi Saruh terhadap status kesehatan seseorang, sanitasi lingkungan terdiri dari ketersediaan air bersih, ketersediaan jamban, jenis lantai rumah, dan kebersihan peralatan makan pada setiap rumah tangga. Keadaan lingkungan yang kurang baik lebih mudah terjangkit penyakit seperti diare dan penyakit infeksi. Ketersediaan air bersih untuk kebutuhan sehari-hari juga berpengaruh terhadap risiko keluarga dan anak terkena penyakit infeksi dan kurang gizi. Faktor sanitasi lingkungan, perilaku hidup bersih dan sehat, serta akses pemanfaatan pelayanan kesehatan akan mempengaruhi penyakit infeksi anak. Kemudian faktor ini secara langsung akan mempengaruhi status gizi. Faktor asupan gizi dan penyakit infeksi secara langsung mempengaruhi status gizi. (Erna Kusumawati, 2015)

Sanitasi lingkungan yang buruk berdampak negatif bagi warga yang mendiami lingkungan tersebut, termasuk anak-anak. Sebab, dapat mengakibatkan mengalami Environmental Enteropathy (EE) yaitu penyebab utama kurang gizi anak berupa kondisi subklinis usus halus. Environmental Enteropathy menimbulkan kerusakan pada jonjot atau vili usus besar sehingga susah menyerap nutrisi. Kemudian, rentan terjadi diare kronis, sehingga dapat menyebabkan kurangnya asupan gizi. (Direktorat Kesehatan Lingkungan, 2018)

Stunting adalah masalah gizi kronis yang disebabkan oleh asupan gizi yang kurang dalam waktu lama. Hal ini terjadi karena asupan makan yang tidak sesuai 
Jurnal Sulolipu : Media Komunikasi Sivitas Akademika dan Masyarakat

Vol. 21 No. 12021

e-issn: 2622-6960, p-issn : 0854-624X

dengan kebutuhan gizi. Stunting adalah indikator kunci kesejahteraan anak secara keseluruhan, negara-negara dengan angka stunting tinggi merefleksi ketidaksetaraan sosial di dalamnya. (Anindhita Maharrani, 2019)

Stunting terjadi mulai dari dalam kandungan dan baru terlihat saat anak berusia dua tahun. Menurut UNICEF, stunting didefinisikan sebagai persentase anak-anak usia 0 sampai 59 bulan, dengan tinggi di bawah minus (stunting sedang dan berat) dan minus tiga (stunting kronis) diukur dari standar pertumbuhan anak keluaran WHO. Berdasarkan ambang batas prevalensi stunting dari $\mathrm{WHO}$ mengategorikan angka stunting 20 sampai kurang dari 30 persen sebagai tinggi, dan lebih dari atau sama dengan 30 persen sangat tinggi. Terdapat 44 negara lain dalam kategori angka stunting sangat tinggi. WHO mencatat, 60 dari 134 negara masih memiliki tingkat stunting di bawah standar 20 persen. WHO juga menjadikan stunting sebagai fokus Global Nutrition Targets untuk 2025, dan Sustainable Development Goals untuk 2030. (Anindhita Maharrani, 2019)

Organisasi Kesehatan Dunia (WHO) menempatkan Indonesia sebagai negara ketiga dengan angka prevalensi stunting tertinggi di Asia pada 2017, dengan angkanya mencapai $36,4 \%$. Kemudian berdasarkan data Riset Kesehatan Nasional (Riskesdas, 2018) yang diolah Lokadata Beritagar.id menunjukkan, 30,8 persen balita di Indonesia mengalami stunting pada tahun 2018. Angka ini meningkat jika dibandingkan pada tahun 2015 yaitu 28,9 persen.

Sanitasi Total Berbasis Masyarakat (STBM) merupakan pendekatan untuk merubah perilaku higiene dan sanitasi melalui pemberdayaan masyarakat dengan metode pemicuan. STBM menjadi acuan nasional untuk program sanitasi berbasis masyarakat sejak lahirnya Kepmenkes No 852/Menkes/SK/IX/2008 tentang Strategi Nasional Sanitasi Total Berbasis masyarakat. (Kementerian Kesehatan RI, 2014)

$$
\text { Beberapa penelitian telah }
$$

membuktikan bahwa kontribusi penyehatan lingkungan terhadap pengentasan masalah stunting cukup besar, salah satunya penelitian tentang anak-anak di Bangladesh yang terakses air minum bersih, jamban, serta fasilitas CTPS pertumbuhan tinggi badannya $50 \%$ bertambah lebih tinggi dibanding anak yang tidak mendapat akses tersebut.(Muhammad Zen, 2019). Penelitian
Torlesse et al (2016) menunjukkan bahwa terdapat interaksi yang signifikan antara fasilitas sanitasi rumah tangga, pengolahan air rumah tangga dengan stunting. Prevalensi stunting se-cara signifikan lebih tinggi di antara anak-anak yang tinggal di rumah tangga tanpa memiliki jamban dibandingkan yang me-miliki jamban (35,3\% vs $24,0 \%)$; rumah tangga yang tidak menggunakan sabun untuk mencuci tangan dibandingkan dengan mereka yang melakukannya ( $31,6 \%$ vs $25,8 \%)$; dan rumah tangga yang minum air yang tidak diolah dibandingkan dengan yang diolah $(38,2 \%$ vs $27,3 \%)$

Penelitian yang dilakukan oleh Alfadhila Khairil Sinatraya tahun 2019 membuktikan bahwa faktor kualitas fisik air minurm $(p=0,58)$, kepemilikan jamban $(p=0,22)$ dan kebiasaaan cuci tangan beresiko 0,12 kali berisiko lebih tinggi bagi ibu yang memiliki kebiasan cuci tangan kurang baik berperan penting dengan kejadian stunting. Penelitian lain yang sejalan juga dilakukan oleh Fahmi Hafid tahun 2018 tentang program Stop Buang Air Besar Sembarangan (SBABS) terhadap pencegahan stunting yang menunjukkan bahwa rata-rata tinggi badan pada kelompok SBABS lebih tinggi dibanding dengan kelompok desa non SBABS. Selain itu penelitian yang dilakukan oleh Nasrul tahun 2015 di Kabupaten Jeneponto menunjukkan bahwa perilaku pengasuh yang tidak mencuci tangan menggunakan sabun sebelum menyiapkan atau memberi makanan kepada anaknya menjadi salah satu faktor risiko stunting $(p=0,021)$.

Sulawesi Selatan menempati urutan ke-4 yang memiliki prevalensi stunting tinggi di Indonesia, setelah NTT, NTB dan Sulawesi Tenggara, yaitu 35,6 \% pada tahun 2018 . Berdasarkan sebaran wilayah, stunting tertinggi ditemukan di Kabupaten Enrekang yaitu persentase stunting di Enrekang capai $53,7 \%$. Sementara pada pemantauan status gizi (PSG) nasional tahun 2017, angkanya mencapai 45,8 \%. Pada tahun 2018 untuk prevalensi stunting di Enrekang mencapai 42,7\%. (Riskesda, 2018).

\section{Metode \\ Waktu Penelitian}

Waktu dalam penelitian ini terbagi 2 (dua),yaitu

1. Tahapan persiapan yaitu pengambilan data sekunder untuk mengumpulkan literatur, untuk kepentingan Penyusunan Proposal yang 
Jurnal Sulolipu : Media Komunikasi Sivitas Akademika dan Masyarakat

Vol. 21 No.12021

e-issn: 2622-6960, p-issn : 0854-624X

dilaksanakan pada bulan Desember 2019 - Januari 2020.

2. Tahap peneliti pelaksanaan kegiatan penelitian dilaksanakan pada bulan April - Mei 2020.

\section{Jenis Penelitian}

Jenis penelitian yang digunakan adalah deskriptif dengan metode studi kepustakaan (Library Research). Penelitian kepustakaan atau studi lieratur (Library Research) adalah teknik pengumpulan data dengan mengadakan studi penelaahan terhadap buku-buku, literatur-literatur, catatancatatan, laporan-laporan dan jurnal-jurnal yang ada hubungannya dengan masalah yang dipecahkan, dalam hal ini yang relevan dengan pelaksanaan Sanitasi Total Berbasis Masyarakat (STBM) dengan kejadian stunting, kemudian dibaca dan dianalisa dan dibahas sesuai dengan variabel penelitian.

\section{Populasi}

Populasi dalam penelitian dengan studi kepustakaan ini adalah semua jurnal penelitian yang sekaitan dengan judul.

\section{Sampel}

Sampel dalam penelitian dengan studi kepustakaan ini adalah 9 jurnal penelitian yang sekaitan dengan judul.

\section{Pengumpulan Data}

Teknik pengumpulan data dalam penelitian ini yaitu data sekunder. Data sekunder adalah data yang diperoleh dari buku-buku, internet, data dinas kesehatan maupun data puskesmas dan hasil penelitian lainnya yang berhubungan dengan objek penelitian.

\section{Pengolahan Data}

Pengolahan data pada penelitian ini dilakukan dengan menganalisa tiap sampel melalui analisis tujuan, kesesuaian topik, metode penelitian yang digunakan, ukuran sampel dan hasil dari setiap sampel.

\section{Penyajian Data}

Data yang dihasilkan berdasarkan hasil dari pengumpulan jurnal yang relevan dengan pilar I stop buang air besar sembarangan (sbabs), pilar II cuci tangan pakai sabun (ctps) dan pilar III pengelolaan air minum dan makanan rumah tangga (pamm-rt) dengan kejadian stunting.

Hasil

Penelitian ini dilaksanakan dengan menganalisis isi dari 9 jurnal terkait dengan Stunting, Sanitasi Total Berbasis Masyarakat (STBM), stop buang air besar sembarangan (sbabs), cuci tangan pakai sabun (ctps), dan pengelolaan air minum dan makanan rumah tangga (pamm-rt). Kemudian, dilakukan penelaahan isi jurnal berhubungan dengan pelaksanaan Sanitasi Total Berbasis Masyarakat (STBM) dengan kejadian stunting.

\section{Tabel 1 Sumber Data Penelitian}

\begin{tabular}{|c|c|c|c|}
\hline No. & Peneliti & Judul Penelitian & Tahun \\
\hline 1 & $\begin{array}{l}\text { Zairinayanti, } \quad \text { Rio } \\
\text { Purnama }\end{array}$ & $\begin{array}{l}\text { Hubungan Hygiene dan Sanitasi Lingkungan dengan } \\
\text { Kejadian Stunting Pada Balita }\end{array}$ & 2019 \\
\hline 2 & $\begin{array}{l}\text { Fahmi Hafid, Udin } \\
\text { Djabu, Udin, Nasrul }\end{array}$ & $\begin{array}{l}\text { Efek Program SBABS Terhadap Pencegahan Stunting Anak } \\
\text { Baduta di Kabupaten Banggai dna Sigi }\end{array}$ & 2017 \\
\hline 3 & $\begin{array}{l}\text { Siti Nur Ramdaniati, Dian } \\
\text { Nastiti }\end{array}$ & $\begin{array}{l}\text { Hubungan Karakteristik Balita, Pengetahuan Ibu dan } \\
\text { Sanitasi Terhadap Kejadian Stunting pada Balita di Kecamatan } \\
\text { Labuan Kabupaten Pandeglang }\end{array}$ & 2019 \\
\hline 4 & $\begin{array}{l}\text { Nasrul, Hafmid Hafid, } \\
\text { A. Razak Thaha, } \\
\text { Suriah }\end{array}$ & $\begin{array}{l}\text { Faktor Risiko Stunting Usia 6-23 Bulan di Kecamatan Bontoramba } \\
\text { Kabupaten Jeneponto }\end{array}$ & 2015 \\
\hline 5 & $\begin{array}{l}\text { Yuliani } \quad \text { Soeracmad, } \\
\text { Muhammad Ikhtiar, Agus } \\
\text { Bintara S }\end{array}$ & $\begin{array}{l}\text { Hubungan Sanitasi Lingkungan Rumah Tangga Dengan Kejadian } \\
\text { Stunting pada Anak Balita di Puskesmas Wonomulyo Kabupaten } \\
\text { Polewali Mandar }\end{array}$ & 2019 \\
\hline 6 & $\begin{array}{l}\text { Zul Fikar Ahmad, Siti } \\
\text { Surya Indah Nurdin }\end{array}$ & $\begin{array}{l}\text { Faktor Lingkungan dan Perilaku Orang Tua pada Balita } \\
\text { Stunting di Kabupaten Gorontalo }\end{array}$ & 2019 \\
\hline 7 & $\begin{array}{lr}\text { Alfadhila } & \text { Khairil } \\
\text { Sinatraya, } & \text { Lailatul } \\
\text { Muniroh } & \end{array}$ & $\begin{array}{l}\text { Hubungan Faktor Water, Sanitation, and Hygiene (WASH) dengan } \\
\text { Kejadian Stunting di Wilayah Kerja Puskesmas Kotakulon } \\
\text { Kabupaten Bondowoso }\end{array}$ & 2019 \\
\hline 8 & $\begin{array}{l}\text { Dewi Khairiyah, } \\
\text { Adhila Fayasari }\end{array}$ & $\begin{array}{l}\text { Perilaku Higiene dan Sanitasi Meningkatkan Risiko } \\
\text { Kejadian Stunting Balita Usia 12-59 bulan di Banten }\end{array}$ & 2020 \\
\hline 9 & $\begin{array}{l}\text { Chamilia Desyanti, } \\
\text { Triska Susila Nindya }\end{array}$ & $\begin{array}{l}\text { Hubungan Riwayat Penyakit Diare dan Praktik Higiene } \\
\text { dengan Kejadian Stunting pada Balita Usia 24-59 Bulan di Wilayah } \\
\text { Kerja Puskesmas Simolawang, Surabaya }\end{array}$ & 2017 \\
\hline
\end{tabular}


Jurnal Sulolipu : Media Komunikasi Sivitas Akademika dan Masyarakat

Vol. 21 No.12021

e-issn: 2622-6960, p-issn : 0854-624X

Tabel 2

Jurnal Hubungan Pilar I Stop Buang Air Besar Sembarangan (SBABS) Dengan Kejadian Stunting

\begin{tabular}{|c|c|c|c|c|c|}
\hline No. & Peneliti, Tahun & $\begin{array}{c}\text { Judul } \\
\text { Penelitian }\end{array}$ & Desain & Tujuan & Hasil \\
\hline 1 & $\begin{array}{l}\text { Zairinayanti, Rio } \\
\text { Purnama } 2019\end{array}$ & $\begin{array}{l}\text { Hubungan } \\
\text { Hygiene dan } \\
\text { Sanitasi } \\
\text { Lingkungan } \\
\text { dengan Kejadian } \\
\text { Stunting Pada } \\
\text { Balita }\end{array}$ & $\begin{array}{l}\text { Case } \\
\text { Control }\end{array}$ & $\begin{array}{l}\text { Mengetahui } \\
\text { hubungan kondisi } \\
\text { hygiene sanitasi } \\
\text { lingkungan (jenis } \\
\text { jamban, sumber } \\
\text { air bersih, } \\
\text { kejadian diare, } \\
\text { kejadian } \\
\text { kecacingan) } \\
\text { dengan kejadian } \\
\text { stunting pada } \\
\text { balita }\end{array}$ & $\begin{array}{l}\text { Anak yang menderita } \\
\text { stunting sebesar } 43,3 \% \\
\text { erada pada rentang umur } \\
3,2-3,9 \text { tahun, memiliki berat } \\
\text { badan } 9-15 \mathrm{~kg} \text { sebanyak } \\
73,3 \% \text { dan } 97 \% \text { keluarga } \\
\text { memliki pendapatan rendah. } \\
\text { Hasil uji bivariat didapatkan } \\
\text { ada hubungan antara jenis } \\
\text { jamban, sumber air bersih } \\
\text { dengan kejadian stunting } \\
\text { pada balita. }\end{array}$ \\
\hline 2 & $\begin{array}{l}\text { Fahmi Hafid,Udin } \\
\text { Djabu, Udin, Nasrul } \\
2017\end{array}$ & $\begin{array}{l}\text { Efek Program } \\
\text { SBABS } \\
\text { Terhadap } \\
\text { Pencegahan } \\
\text { Stunting Anak } \\
\text { Baduta di } \\
\text { Kabupaten } \\
\text { Banggai dna } \\
\text { Sigi }\end{array}$ & $\begin{array}{l}\text { Case } \\
\text { Control }\end{array}$ & $\begin{array}{l}\text { Menganalisis } \\
\text { pengaruh } \\
\text { program stop } \\
\text { buang air besar } \\
\text { sembarangan } \\
\text { terhadap } \\
\text { pencegahan } \\
\text { stunting anak } \\
\text { baduta di } \\
\text { Kabupaten } \\
\text { Banggai dan Sigi }\end{array}$ & $\begin{array}{l}\text { Proporsi baduta stunting } \\
\text { sebesar } 15,6 \% \text {. Jumlah } \\
\text { sampel pada kelompok } \\
\text { SBABS sebanyak } 116 \text { orang } \\
\text { (33,0\%) dengan rerata tinggi } \\
\text { badan }-0,36 \pm 1,6 \text { sedangkan } \\
\text { pada kelompok non } \\
\text { SBABS sebanyak } 236 \text { orang } \\
(67,0 \%) \text { dengan rerata tinggi } \\
\text { badan }-0,94 \pm 1,5 \text {, terdapat } \\
\text { perbedaan yang bermakna } \\
\text { antara pertumbuhan baduta } \\
\text { kelompok SBABS dengan } \\
\text { non SBABS ( } \mathrm{p}=0,002)\end{array}$ \\
\hline 3 & $\begin{array}{l}\text { Siti Nur } \\
\text { Ramdaniati, Dian } \\
\text { Nastiti } 2019\end{array}$ & $\begin{array}{l}\text { Hubungan } \\
\text { Karakteristik } \\
\text { Balita, } \\
\text { Pengetahuan } \\
\text { lbu dan Sanitasi } \\
\text { Terhadap } \\
\text { Kejadian } \\
\text { Stunting pada } \\
\text { Balita di } \\
\text { Kecamatan } \\
\text { Labuan } \\
\text { Kabupaten } \\
\text { Pandeglang }\end{array}$ & $\begin{array}{l}\text { Case } \\
\text { Control }\end{array}$ & $\begin{array}{l}\text { Mengetahui } \\
\text { hubungan } \\
\text { karakteristik } \\
\text { balita, } \\
\text { pengetahuan ibu } \\
\text { dan sanitasi } \\
\text { terhadap } \\
\text { kejadian stunting }\end{array}$ & $\begin{array}{l}\text { Terdapat hubungan } \\
\text { signifikan antara Berat Badan } \\
\text { Lahir Rendah (BBLR), } \\
\text { pengetahuan ibu, } \\
\text { kepemilikan jamban dan } \\
\text { sumber air terhadap kejadian } \\
\text { stunting pada balita di } \\
\text { Kecamatan Labuan }\end{array}$ \\
\hline
\end{tabular}


Tabel 3

Jurnal Hubungan Pilar II Cuci Tangan Pakai Sabun (CTPS) dengan Kejadian Stunting

\begin{tabular}{|c|c|c|c|c|c|}
\hline No. & Peneliti, Tahun & $\begin{array}{l}\text { Judul } \\
\text { Penelitian }\end{array}$ & Desain & Tujuan & Hasil \\
\hline 1 & $\begin{array}{l}\text { Nasrul, Hafmid Hafid, } \\
\text { A. Razak Thaha, Suriah } \\
2015\end{array}$ & $\begin{array}{l}\text { Faktor Risiko } \\
\text { Stunting Usia } \\
6-23 \text { Bulan di } \\
\text { Kecamatan } \\
\text { Bontoramba } \\
\text { Kabupaten } \\
\text { Jeneponto }\end{array}$ & $\begin{array}{l}\text { Cros } \\
\text { Sectional }\end{array}$ & $\begin{array}{l}\text { Menganalisis } \\
\text { faktor risiko } \\
\text { stinting anak } \\
\text { usia 6-23 bulan } \\
\text { di kecamatan } \\
\text { Bontoramba } \\
\text { Kabupaten } \\
\text { Jeneponto }\end{array}$ & $\begin{array}{l}\text { Faktor risiko stunting dalam } \\
\text { penelitian ini adalah (OR: } p \text { value), } \\
\text { berat badan lahir rendah (OR=3,651 } \\
; \mathrm{P}=0,002), \text { usia anak } 12-23 \text { bulan } \\
\text { (OR=2,708; } \mathrm{P}=0,000) \text {, tinggi badan } \\
\text { ibu }<50 \mathrm{~cm} \text { dengan (OR-1,970; } \\
\mathrm{p}=0,006) \text {, pengasuh tidak mencuci } \\
\text { tangan dengan sabun }(\mathrm{OR}=2,708 ; \\
\mathrm{p}=0,021) \text { dan imunisasi dasar } \\
\text { yang tidak lengkap (OR=1,640; } \\
\mathrm{p}=0,037)\end{array}$ \\
\hline 2 & $\begin{array}{l}\text { Yuliani } \\
\text { Soeracmad,Muhammad } \\
\text { lkhtiar,Agus Bintara S } \\
2019\end{array}$ & $\begin{array}{l}\text { Hubungan } \\
\text { Sanitasi } \\
\text { Lingkungan } \\
\text { Rumah } \\
\text { Tangga } \\
\text { Dengan } \\
\text { Kejadian } \\
\text { Stunting pada } \\
\text { Anak Balita di } \\
\text { Puskesmas } \\
\text { Wonomulyo } \\
\text { Kabupaten } \\
\text { Polewali } \\
\text { Mandar }\end{array}$ & $\begin{array}{l}\text { Case } \\
\text { Control }\end{array}$ & $\begin{array}{l}\text { Mengnalisis } \\
\text { faktor risiko } \\
\text { sanitasi } \\
\text { lingkungan } \\
\text { rumah tangga } \\
\text { dengan } \\
\text { kejadian } \\
\text { stunting pada } \\
\text { balita di } \\
\text { Puskesmas } \\
\text { Wonomulyo } \\
\text { Kabupaten } \\
\text { Polewali } \\
\text { Mandar }\end{array}$ & $\begin{array}{l}\text { Menjelaskan bahwa cuci tangan } \\
\text { pakai sabun di air mengalir } \\
\text { merupakan } 2 \text { kali beresiko } \\
\text { terjadinya stunting dengn nilai } p \\
0,000>0,05 \text { artinya secara statistik } \\
\text { mempunyai pengaruh yang } \\
\text { bermakan antara cuci tangan di air } \\
\text { mengaalir pakai sabun dengan } \\
\text { kejadian stunting. Sedangkan } \\
\text { pengamanan sampah rumah tangga } \\
\text { beresiko } 2 \text { kali kejadian stunting } \\
\text { dengan nilai p } 0,000>0,05 \text { artinya } \\
\text { secara statitik pengaruh yang } \\
\text { bermakna antara pengamanan } \\
\text { sampah rumah tangga dengan } \\
\text { kejadian stunting.dan pengelolaan } \\
\text { air minum dan makanan rumah } \\
\text { tangga } 2 \text { kali beresiko terjadinya } \\
\text { stunting dengan nila p } 1,000>0,05 \\
\text { dimana secara statistika tidak } \\
\text { memiliki pengaruh yang bermakna } \\
\text { antara pengelolaan air minum dan } \\
\text { makanan rumah tangga terhadap } \\
\text { kejadian stunting.Kemudian } \\
\text { pengamanan saluran pembuangan } \\
\text { air limbah } 2 \text { kali beresiko terjadinya } \\
\text { stunting dengan nilai } p 0,000>0,05 \\
\text { artinya secara statistik mempunyai } \\
\text { pengaruh yang bermakna antara } \\
\text { pengelolaan saluran pembuangan } \\
\text { air limbah rumah tangga dengan } \\
\text { kejadian stunting }\end{array}$ \\
\hline 3 & $\begin{array}{l}\text { Zul Fikar Ahmad,Siti } \\
\text { Surya Indah Nurdin } \\
2019\end{array}$ & $\begin{array}{l}\text { Faktor } \\
\text { Lingkungan } \\
\text { dan Perilaku } \\
\text { Orang Tua } \\
\text { pada Balita } \\
\text { Stunting di } \\
\text { Kabupaten } \\
\text { Gorontalo }\end{array}$ & $\begin{array}{l}\text { Case } \\
\text { Control }\end{array}$ & $\begin{array}{l}\text { Menganalisis } \\
\text { faktor } \\
\text { lingkungan dan } \\
\text { perilaku orang } \\
\text { tua pada kasus } \\
\text { stunting anak } \\
\text { usia kurang } \\
\text { dari } 5 \text { tahun di } \\
\text { kabupaten } \\
\text { Gorontalo } \\
\end{array}$ & $\begin{array}{l}\text { Menunjukkan riwayat diare } \\
\text { yang sering, kurangnya akses } \\
\text { air bersih, dan terpapar asap } \\
\text { rokok merupakan faktor risiko } \\
\text { kejadian stunting.Kebiasaan } \\
\text { cuci tangan pakai sabun } \\
\text { merupakan faktor protektif } \\
\text { terhadap kejadian stunting }\end{array}$ \\
\hline 4 & $\begin{array}{l}\text { Alfadhila Khairil } \\
\text { Sinatraya,Lailatul } \\
\text { Muniroh } 2019\end{array}$ & $\begin{array}{l}\text { Hubungan } \\
\text { Faktor Water, } \\
\text { Sanitation, } \\
\text { and Hygiene } \\
\text { (WASH) } \\
\text { dengan } \\
\text { Kejadian } \\
\text { Stunting di } \\
\text { Wilayah Kerja } \\
\text { Puskesmas } \\
\text { Kotakulon } \\
\text { Kabupaten } \\
\text { Bondowoso }\end{array}$ & $\begin{array}{l}\text { Case } \\
\text { Control }\end{array}$ & Menganalisis & $\begin{array}{l}\text { Kebiasaaan cuci tangan } \\
(p>0,001 ; \text { OR=0,12) adalah } \\
\text { faktor risiko dari stunting pada } \\
\text { balita dengan besar risiko } 0,12 \\
\text { kali lebih tinggi bagi ibu yang } \\
\text { memiliki kebiasaan cuci tangan } \\
\text { kursng baik, sedangkan } \\
\text { sumber air minum }(p=0,415) \text {, } \\
\text { kualitas fisik air minum } \\
(p<0,58) \text {, kepemilikan jamban } \\
(p=0,22) \text { bukan meruapakan } \\
\text { faktor risiko Stunting }\end{array}$ \\
\hline
\end{tabular}


Tabel 4

Jurnal Hubungan Pilar III Pengelolaan Air Minum dan Makanan Rumah Tangga (PAMMRT) dengan Kejadian Stunting

\begin{tabular}{|c|c|c|c|c|c|}
\hline No. & Peneliti, Tahun & Judul Penelitian & Desain & Tujuan & Hasil \\
\hline 1 & $\begin{array}{l}\text { Dewi } \\
\text { Khairiyah, } \\
\text { Adhila } \\
\text { Fayasari } 2020\end{array}$ & $\begin{array}{l}\text { Perilaku Higiene } \\
\text { dan Sanitasi } \\
\text { Meningkatkan } \\
\text { Risiko Kejadian } \\
\text { Stunting Balita } \\
\text { Usia 12-59 } \\
\text { bulan di Banten }\end{array}$ & $\begin{array}{l}\text { Case } \\
\text { Control }\end{array}$ & $\begin{array}{l}\text { Menganalisisi hubungan } \\
\text { antara higiene dan } \\
\text { sanitasi dengan kejadian } \\
\text { stunting pada balita usia } \\
12-59 \text { bulan di wilayah } \\
\text { kerja puskesmas } \\
\text { Mandala, Banten }\end{array}$ & $\begin{array}{l}\text { Subjek dengan higiene yang } \\
\text { buruk memepunyai risiko } \\
\text { terjadi stunting ( } \mathrm{p}=0,000 ; \\
\text { OR=27,28), begitu pula } \\
\text { sanitasi lingkungan yang } \\
\text { buruk memiliki korelasi } \\
\text { positif dan berkekuatan } \\
\text { sedang dengan terjadinya } \\
\text { stunting ( } \mathrm{p}=0,000 ; \mathrm{r}=0,511) . \\
\text { Kelompok balita stunting } \\
\text { cenderung memiiki erilaku } \\
\text { higiene dan kondisi sanitasi } \\
\text { lingkungan yang lebih buruk } \\
\text { daripada kelompok tidak } \\
\text { stunting }\end{array}$ \\
\hline 2 & $\begin{array}{l}\text { Chamilia } \\
\text { Desyanti, } \\
\text { Triska Susila } \\
\text { Nindya } \\
2017\end{array}$ & $\begin{array}{l}\text { Hubungan } \\
\text { Riwayat } \\
\text { Penyakit Diare } \\
\text { dan Praktik } \\
\text { Higiene dengan } \\
\text { Kejadian } \\
\text { Stunting pada } \\
\text { Balita Usia 24 } \\
59 \text { Bulan di } \\
\text { Wilayah Kerja } \\
\text { Puskesmas } \\
\text { Simolawang, } \\
\text { Surabaya }\end{array}$ & $\begin{array}{l}\text { Case } \\
\text { Control }\end{array}$ & $\begin{array}{l}\text { Menganalisis hubungan } \\
\text { riwayat penyakit diare } \\
\text { dan praktik higiene } \\
\text { dengan kejadian stunting } \\
\text { pada balita usia } 24-59 \\
\text { bulan. }\end{array}$ & \begin{tabular}{|l} 
Sebagian besar anak pada \\
kelompok stunting sering \\
mengalami diare $(72,7 \%)$ \\
sedangkan pada kelompok \\
tidak stunting jarang \\
mengalami diare $(57,6 \%)$. \\
Sebagian besar pengasuh \\
pada kelompok stunting \\
memiliki praktik higiene yang \\
buruk $(75,8 \%)$, sedangkan \\
pada kelompok tidak stunting \\
memiliki praktik higiene yang \\
baik $(60,6 \%)$. Riwayat \\
penyakit diare ( $p=0,025$, \\
OR=3,619) dan praktik \\
higiene ( $p=0,006$, \\
OR=4,808) memiliki \\
hubungan yang signifikan \\
dengan kejadian stunting
\end{tabular} \\
\hline
\end{tabular}


Jurnal Sulolipu : Media Komunikasi Sivitas Akademika dan Masyarakat

Vol. 21 No. 12021

e-issn: 2622-6960, p-issn : 0854-624X

\section{Pembahasan}

1. Hubungan Pilar I Stop Buang Air Besar Sembarangan (SBABS) Dengan Upaya Penurunan Angka Stunting

Berdasarkan hasil kajian jurnaljurnal yang berkaitan tentang faktor risiko terjadinya stunting dari 4 jurnal yang berkaitan dengan hubungan pilar I stop buang air besar sembarangan (sbabs) dengan kejadian stunting yang dapat berperan sebagai upaya penurunan angka stunting. Maka, dari kajian beberapa jurnal dapat dijelaskan bahwa perilaku Buang Air Besar Sembarangan (BABS) dikarenakan tidak memiliki fasilitas jamban sehat, erat kaitannya dengan tingginya angka kejadian diare yang dapat mempengaruhi tumbuh kembang balita. Oleh karena itu penting bagi setiap keluarga agar memiliki jamban sehat. Hal ini dikarenakan perilaku buang air besar sembarangan dapat mengakibatkan munculnya enviromental enteropathy yaitu penyebab utama kurang gizi anak berupa kondisi subklinis usus halus. Environmental Enteropathy menimbulkan kerusakan pada jonjot atau vili usus besar sehingga susah menyerap nutrisi. Kemudian, rentan terjadi diare kronis, sehingga dapat menyebabkan kurangnya asupan gizi. Hal inilah yang menyebabkan malnutrisi dalam waktu yang lama yaitu stunting.

Salah satu upaya penting untuk meningkatkan derajat kesehatan adalah pengadaan lingkungan fisik yang sehat bagi masyarakat jamban pada umumnya dan khususnya jamban keluarga merupakan salah satu sarana yang diperlukan untuk mewujudkan lingkungan bersih dan sehat. Dengan tersedianya jamban yang memenuhi syarat kesehatan sehingga dapat terhindar dari penyebaran penyakit. Pengaruh jamban yang tidak sehat terhadap penyakit diare sehingga membawa efek terhadap penurunan tingkat kesehatan (Tarigan, 2008).

Standar dan persyaratan kesehatan bangunan jamban yang terdiri dari bangunan atas jamban berupa dinding dan atap harus berfungsi untuk melindungi pemakai dari gangguan cuaca dan gangguan lainnya, bangunan tengah jamban berupa lubang tempat pembuangan kotoran (tinja dan urine) yang saniter dilengkapi dengan konstruksi leher angsa, lantai jamban dari bahan kedap air, tidak licin dan mempunyai saluran untuk pembuangan air limbah, dan bangunan bawah yang berfungsi mencegah terjadinya pencemaran atau kontaminasi dari tinja melalui vektor pembawa penyakit baik secara langsung maupun tidak langsung. (Permenkes No 3 tahun 2014)

Jamban yang tidak memenuhi standar secara teori berpotensi memicu timbulnya penyakit infeksi yang karena higiene dan sanitasi yang buruk (misalnya diare dan kecacingan) yang dapat menganggu penyerapan nutrisi pada proses pencernaan. Beberapa penyakit infeksi yang diderita bayi dapat menyebabkan berat badan bayi turun. Jika kondisi ini terjadi dalam waktu yang cukup lama dan tidak disertai dengan pemberian asupan yang cukup untuk proses penyembuhan maka dapat mengakibatkan stunting.

Jamban sehat efektif untuk memutus mata rantai penularan penyakit. Jamban sehat harus dibangun, dimiliki dan digunakan oleh keluarga dengan penempatan (di dalam rumah atau di luar rumah) yang mudah dijangkau oleh penghuni rumah (Kemenkes RI, 2014).

Setiap anggota rumah tangga harus menggunakan jamban untuk buang air besar/buang air kecil. Penggunaan jamban akan bermanfaat untuk menjaga lingkungan bersih, sehat, dan tidak berbau. Jamban mencegah pencemaran sumber air yang ada disekitarnya. Jamban juga tidak mengundang datangnya lalat atau serangga yang dapat menjadi penular penyakit Diare, Kolera Disentri, Typus, Kecacingan, penyakit saluran pencernaan, penyakit kulit, dan keracunan. (Eni Rahmawati, 2012).

Kotoran manusia adalah semua benda atau zat yang tidak dipakai lagi oleh tubuh dan harus dikeluarkan dari dalam tubuh. Beberapa zat-zat tersebut adalah tinja (feses), air seni (urine), dan $\mathrm{CO} 2$ sebagai hasil proses pernapasan. Selain itu juga tinja merupakan buangan padat yang dapat menimbulkan bau, mengotori lingkungan juga merupakan media penularan penyakit pada masyarakat.

Pembuangan tinja atau kotoran manusia di sembarang tempat atau bukan pada tempatnya dapat menimbulkan gangguan terhadap kesehatan manusia, dimana tinja adalah media perantara lingkungan antara lain dapat menimbulkan bau dan merupakan tempat bersarangnya vektor. 
Perjalanan agent ini dapat melalui berbagai cara transmisi, yaitu melalui jarijari tangan, makanan/minuman maupun peralatan-peralatan yang terkontaminasi serta melalui lantai lainnya yang melalui tinja yang mengandung agent penyakit masuk melalui saluran pencernaan.

\section{Hubungan Pilar II Cuci Tangan Pakai} Sabun (CTPS) Dengan kejadian Stunting

Berdasarkan hasil kajian jurnaljurnal yang berkaitan tentang faktor risiko terjadinya stunting dari 4 jurnal yang berkaitan dengan hubungan pilar II cuci tangan pakai sabun (ctps) diwaktu penting dengan kejadian stunting yang dapat berperan sebagai upaya penurunan angka stunting.

Maka, dari beberapa jurnal yang dikaji dapat dijelaskan cuci tangan pakai sabun (ctps) dapat berperan dalam upaya penururunan angka stunting. CTPS adalah cara yang sederhana, mudah, murah dan bermanfaat untuk mencegah berbagai penyakit. Sebab, ada beberapa penyakit penyebab kematian yang dapat dicegah dengan cuci tangan yang benar, seperti penyakit Diare dan ISPA yang sering menjadi penyebab kematian anak-anak. Demikian juga penyakit Hepatitis, Typhus, dan Flu Burung. Karena itu, biasakan cuci tangan pakai sabun (CTPS) pda waktuwaktu yang penting, yaitu sebelum makan, sebelum memegang, mengolah, menyiapkan makanan, setelah buang air besar, serta setelah kontak dengan hewan dan tanah.

Di sisi lain, mencuci tangan pakai sabun bisa menurunkan risiko diare hingga $45 \%$. Diare merupakan penyakit yang sering menyerang anak-anak. Jika seorang anak diare berulang, terutama di periode 1000 hari pertama kehidupan, kemungkinan besar dia tidak akan mendapatkan gizi yang cukup. Kekurangan gizi itulah yang menyebabkan stunting pada anak.

Anak rajin mencuci tangan, dapat menurunkan risiko diare. Apabila diare tidak terjadi, maka nutrisi yang dikonsumsinya dapat diserap dengan baik oleh tubuh sehingga menurunkan risiko stunting. Di sinilah letak keterkaitan antara mencuci tangan pakai sabun dengan stunting.

Mencuci tangan adalah salah suatu tindakan sanitasi dengan membersihkan tangan dan jari jemari dengan menggunakan air ataupun cairan lainnya oleh manusia dengan tujuan untuk menjadi bersih dari kotoran dan membunuh kuman yang dapat menyebabkan penyakit.

Dalam mencuci tangan ada tujuh langkah yang harus dipahami diantaranya mencuci diair yang mengalir, menggunakan sabun, menggosok telapak tangan, punggung tangan, sela-sela jari membilas sampai bersih dan mengeringkan tangan Mencuci tangan juga sebaiknya dilakukan dengan air bersih yang mengalir. Air yang mengalir akan membuat kotoran dan kuman luruh terbawa air. Air yang bersih memiliki ciri jernih, tidak berbau, dan tidak berwarna. Air yang tidak bersih banyak mengandung kuman dan bakteri penyebab penyakit. Bila digunakan, kuman sangat mungkin berpindah ke tangan. Pada saat makan, kuman bisa dengan cepat masuk kedalam tubuh dan menimbulkan penyakit.

Sarana cuci tangan tidak perlu terdiri dari keran dan wastafel yang mewah atau mahal. Sarana CTPS yang sederhana dan yang tept guna yaitu dibuat dari bahan/material yang dapat diperoleh dengan mudah, misalnya : dapat dibuat dari ruas bambu, tempat-tempat bekas seperti botol plastik besar, jerigen, gentong, kaleng besar, dan lain sebagainya, yang dibolongi sehingga air dapat megalir dan ditutup kembali. (Kemenkes RI, 2014)

Sebagian besar kuman penyakit yang mencemari air dan makanan dari proses hewan dan manusia, mencakup bakteri, virus, protozoa dan cacing dan termasuk bersama air dan makanan, atau terbawa ke mulut oleh jari-jari yang tercemar. (Ronny, 2017)

Tangan seringkali menjadi agen yang membawa kuman dan menyebabkan patogen berpindah dari satu orang ke orang lain, baik dengan kontak langsung ataupun kontak tidak langsung (menggunakan permukaan-permukaan lain seperti handuk, gelas). Tangan yang bersentuhan langsung dengan kotoran manusia dan binatang, ataupun cairan tubuh lain (seperti ingus, dan makanan/minuman yang terksontaminasi saat tidak dicuci dengan sabun dapat memindahkan bakteri, virus, dan parasit pada orang lain yang tidak sadar bahwa dirinya sedang ditularkan).

Stunting adalah kondisi gagal tumbuh pada anak hanya terkait sanitasi, namun lebih terkait dengan perilaku. Ada tiga pilar yang harus diperhatikan untuk pencegahan stunting, yaitu pola makan yang bergizi, pola asuh yang baik, serta sanitasi yang sehat. Untuk itu diperlukan 
usaha meningkatkan perilaku hidup bersih dan sehat yang diantaranya cuci tangan pakai sabun (ctps) sebagai upaya preventif dalam pemeliharaan kesehatan dan pencegahan risiko akan dampak stunting

\section{Hubungan Pilar III Pengelolaan Air Minum dan Makanan Rumah Tangga (PAMM-RT) Dengan Kejadian Stunting}

Berdasarkan hasil kajian jurnaljurnal yang berkaitan tentang faktor risiko terjadinya stunting dari 2 jurnal yang berkaitan dengan hubungan pilar III pengelolaan air minum dan makanan rumah tangga (pamm-rt) dengan kejadian stunting yang dapat berperan sebagai upaya penurunan angka stunting.

Maka dari beberapa jurnal yang dikaji dapat dijelaskan bahwa praktik higiene yang buruk dapat menyebabkan anak terserang penyakit diare yang nantinya dapat menyebabkan anak kehilangan zat-zat gizi yang penting bagi pertumbuhan. Kontaminasi makanan serta penyakit infeksi dapat berdampak pada status kesehatan anak. Higiene dan sanitasi merupakan hal yang penting dalam menentukan kualitas makanan dimana Escherichia coli sebagai salah satu indikator terjadinya pencemaran makanan yang dapat menyebabkan penyakit akibat makanan (food borne diseases). E.coli dalam makanan dan minuman merupakan indikator terjadinya kontaminasi akibat penanganan makanan dan minuman yang kurang baik.

Makanan yang sehat yaitu makanan yang higienis dan bergizi. Makanan yang higienis adalah makanan yang tidak mengandung kuman penyakit dan tidak mengandung racun yang dapat membahayakan kesehatan. Bahan makanan yang akan kita makan harus mengandung komposisi gizi yang lengkap, yaitu terdiri atas karbohidrat, lemak, protein, vitamin, mineral, dan air. Di Indonesia komposisi tersebut disebut dengan 4 sehat 5 sempurna. (Munifa, 2014)

Makanan harus dikelola dengan baik dan benar agar tidak menyebabkan gangguan kesehatan dan bermanfaat bagi tubuh. Cara pengelolaan makanan yang baik yaitu dengan menerapkan prinsip hiegen dan sanitasi makanan. Pengelolaan makanan di rumah tangga, walaupun dalam jumlah kecil atau skala rumah tangga juga harus menerapkan prinsip higiene sanitasi makanan. (Kemenkes Rl, 2014)

Higiene sanitasi makanan merupakan upaya kesehatan untuk menyehatkan makanan. Upaya higiene sanitasi makanan (termasuk minuman), bahan makanan dan keamanan makanan di rumah tangga merupakan unsur kesehatan dasar yang sagat penting untuk melindungi seluruh anggota keluarga di dalam rumah tangga, dari gangguan penyakit bawaan makanan.

Dari hasil penelitian ini dapat di ketahui bahwa pengetahuan tentang hygiene makanan mempengaruhi kejadian Diare pada anak, hal ini di sebabkan karena setiap tindakan yang dilakukan sangat di pengaruhi oleh pengetahuan yang dimiliki. $\mathrm{Hal}$ ini menunjukkan bahwa terdapat hubungan antara perilaku tentang higiene dan sanitasi makanan dengan kejadian diare. Penelitian ini sejalan dengan penelitian Astutik dkk (2011) yang menyatakan bahwa terdapat hubungan antara pengetahuan tentang higiene dan sanitasi makanan dengan kejadian diare. (Elsya Yutik, 2014)

Untuk itu perlu pengelolaan makanan yang memenuhi syarat kesehatan yang disebut dengan istilah penyehatan makanan. Pengelolaan higiene sanitasi makanan yang baik harus memperhatikan beberapa faktor yaitu higiene sanitasi tempat, higiene sanitasi peralatan, hygiene penjamah, dan higiene sanitasi makanan yang terdiri dari enam prinsip yaitu pemilihan bahan makanan, penyimpanan bahan makanan, pengolahan makanan, penyimpanan makanan masak, pengangkutan makanan, dan penyajian makanan.

Penjamah makanan adalah seorang tenaga yang menjamah makanan mulai dari mempersiapkan, mengolah, menyimpan, mengangkut maupun dalam penyajian makanan. Pengetahuan, sikap dan prilaku seorang penjamah mempengaruhi kualitas makanan yang dihasilkan. Penjamah juga dapat berperan sebagai penyebar penyakit, hal ini bisa terjadi melalui kontak antara penjamah makanan yang menderita penyakit menular dengan konsumen yang sehat, kontaminasi terhadap makanan oleh penjamah yang membawa kuman.

Pengelolaan makanan yang baik dan memenuhi syarat kesehatan merupakan salah satu upaya untuk 
mencapai tingkat kesehatan masyarakat yang optimal, sehingga perlu mendapat perhatian dari segi nilai gizi, segi kemurnian, maupun dari segi kebersihan. Sebab meskipun nilai gizi dan kemurnian baik namun kebersihan lingkungan tidak diawasi dan dipelihara, maka makanan tersebut dapat menimbulkan penyakit akibat kontaminasi.

Adapun usaha-usaha dalam sanitasi makanan antara lain keamanan makanan dan minuman yang disediakan, hygiene perorangan dan praktek-praktek penanganan makanan oleh penjamah, keamanan terhadap penyediaan air, pengelolaan pembuangan air limbah dan kotor, perlindungan makanan terhadap kontaminasi selama dalam proses pengolahan, penyajian, dan penyimpanan dan pencucian, kebersihan dan penyimpanan alat-alat/perlengkapan.

Air merupakan zat yang sangat penting bagi tubuh manusia. Sekitar 50$70 \%$ tubuh manusia terdiri dari air, termasuk kulit, jaringan tubuh, sel-sel dan seluruh organ. Tidak ada manusia yang dapat bertahan hidup dalam waktu lama jika tubuh kekurangan cairan. Adapun manfaat dari air minum dalam kebutuhan cairan tubuh yaitu mencegah dehidrasi melancarkan sirkulasi darah, membantu mengeluarkan racun, membantu kinerja ginjal, mengontrol nafsu makan, membantu distribusi gizi, menjaga keseimbangan cairan dalam tubuh.

Air dan sanitasi yang buruk dapat berdampak pada tidak adanya penyerapan gizi di pencernaan. Coliform juga menjadi penanda air terkontaminasi patogen atau tidak. Karena memang salah satu parameter apakah air minum terkontaminasi tinja atau tidak itu caranya dengan melihat jumlah Coliformnya, meskipun ada mikroba di makanan, masih ada yang boleh dikonsumsi, tapi syaratnya harus dimasak. Kalau dimasak, bakteri akan mati.

Adapun wadah penyimpanan air minum yang aman dalam kehidupan seharihari adalah wadah bertutup, berleher sempit, dan lebih baik dilengkapi dengan kran, air minum sebaiknya disimpan diwadah pengolahannya, air yang sudah diolah sebaiknya disimpan dalam tempat yang bersih dan selalu tertutup, minum air dengan menggunakan gelas yang bersih dan kering atau tidak minum air langsung mengenai mulut/wadah kran, letakkan wadah penyimpanan air minum di tempat yang bersih dan sulit terjangkau oleh binatang, wadah air minum dicuci setelah tiga hari atau saat air habis, gunakan air yang sudah diolah sebagai air bilasan terakhir. (Permenkes No. 3 tahun 2014)

Faktor lingkungan terutama air yang tidak memenuhi syarat kesehatan karena tercemar bakteri, didukung oleh perilaku manusia yang tidak sehat seperti pembuangan tinja tidak higienis, kebersihan perorangan dan lingkungan yang jelek, serta penyiapan dan penyimpanan makanan yang tidak semestinya, dapat menimbulkan kejadian diare.

\section{Kesimpulan}

Berdasarkan hasil kajian tentang pelaksanaan sanitasi total berbasis masyarakat (stbm) dengan upaya penurunan angka stunting pada balita terkait jurnal yang diperoleh, maka dapat disimpulkan :

1. Ada hubungan sanitasi total berbasis masyarakat pilar I stop buang air besar sembarangan (sbabs) dengan upaya penurunan angka stunting pada balita, hal ini dapat dilihat dari beberapa kajian hasil penelitian sebelumnya yaitu pada jurnal 1 , 2, dan 3 pada tabel 2

2. Ada hubungan sanitasi total berbasis masyarakat pilar II cuci tangan pakai sabun (ctps) dengan upaya penurunan angka stunting pada balita, hal ini dapat dilihat dari beberapa kajian penelitian sebelumnya yaitu pada jurnal 1, 2, 3, dan 4 pada tabel 3

3. Ada hubungan sanitasi total berbasis masyarakat pilar III pengelolaan air minum dan makanan rumah tangga (pamm-rt) dengan upaya penurunan angka stunting pada balita, hal ini dapat dilihat dari beberapa jurnal kajian penelitian sebelumnya yaitu pada jurnal 1 , dan pada tabel 4

\section{Saran}

1. Untuk masyarakat : Diharapkan agar masyarakat lebih bereperan aktif dalam memperhatikan kebersihan linkungan dan menerapkan perilaku hidup bersih dan sehat sebagai suatu upaya pencegahan dan penurunan angka stunting.

2. Untuk Instantsi terkait : Diharapkan perlu dilakukan sosialisasi dan penyuluhan mendalam kepada masyarakat tentang Sanitasi Total Berbasis Masyarakat (STBM) dan stunting. Penyuluhan ini diharapkan 
Jurnal Sulolipu : Media Komunikasi Sivitas Akademika dan Masyarakat

Vol. 21 No. 12021

e-issn: 2622-6960, p-issn : 0854-624X

memberikan kesadaran dalam mengubah perilaku masyarakat serta melakukan edukasi kesehatan kepada ibu balita dan ibu hamil serta pemeriksaan secara berkala agar pertumbuhan bayiiu dalam kandungan terpantau dengan baik sesuai kandungan.

\section{DAFTAR PUSTAKA}

Alfadhila Khairil S, Lailatul Muniroh. 2019. Hubungan Faktor Water. Sanitation, and Hygiene (WASH) dengan Stunting di Wilayah Kerja Puskesmas Kutakulon, Kabupaten Bondowoso.

Doi: 10.2473/amnt.v3i3.2019.164-

170.(online).https://e-

journal.unair.ac.id/AMNT/article/vie w/13153. Diakses 5 Januari 2020

Allen, L., \& Gillespie, S. (2001). A Review of the Efficacy and effectiveness of Nutrition Intervention. Nutrition Policy Paper,15.https://pdfs.semanticscholar.org/a 205/cb980bb70c58cc288fc291022c5 97cd60938.pdf. diakses 7 Januari 2020

Amaliyah, Nurul. 2015. Penyehatan Makanan dan Minuman-A. Ed. 1. Yogyakarta: Deepublish.

Anindhita Maharrani. 2019. Gentingnya Masalah Stunting di Indonesia. (online) https://beritagar.id/artikel/berita/gentingnya-masalah-stunting-di-indonesia. Diakses 7 Januari 2020

Arfiah, Patmawati, Afriani. 2018. Gambaran Pelaksanaan Sanitasi Total Berbasis Masyarakat (STBM) di Desa Padang Timur Kecamatan Campalagian Kabupaten Polewali Mandar. Vol 4. No2. (online) https://www.neliti.com/id/publication s/283681/gambaran-pelaksanaansanitasi-total-berbasis-masyarakat- stbm-di-desa-padang-timur

Chamilia Desyanti, Triska Susila Nindya. 2017. Hubungan Riwayat Penyakit Diare dan Praktik Higiene dengan Kejadian Stunting pada Balita Usia 24-59 Bulan di Wilayah Kerja Puskesmas Simolawang, Surabaya.DOI 10.2473/amnt.v1i3.2017.243-251.

https://www.researchgate.net/publication/321829688_Hubungan_Riwayat_Penyakit_Diare_dan Praktik_Higiene_dengan_Kejadian_Stunting_pada_Balita_Usia_24-

59_Bulan_di_Wilayah_Kerja_Puskes mas_Simolawang_Surabaya

Crocker J, Geremew A, Atalie F. 2016. Teachers and Sanitation Promotion: An Assessment of Community Led Total Sanitation In Ethiopia. DOI: 10.1021/acs.est.6b01021. https://www.ncbi.nlm.nih.gov/pubme d/27211881

Danaei G,Andrews K,Sudfeld C. 2016. Risk Factors for Childhood Stunting in 137 Developing Countries: A Comparative Risk Assessment Analysis at Global, Regional, and Country Levels. DOI: 10.1371/journal.pmed.1002164. https://www.ncbi.nlm.nih.gov/pubme $\mathrm{d} / 27802277$

de Onis, M., \& Branca, F. (2016). Childhood stunting: A global perspective. Maternal and Child Nutrition. https://doi.org/10.1111/mcn.12231. (Online). Diakses tanggal 4 januari 2020

Departemen Kesehatan RI. 2011. Buku Saku Petugas Kesehatan.

Dewi Khairiyah, Adhila Fayasari. 2020. Perilaku Higiene dan Sanitasi Meningkatkan Risiko Kejadian Stunting Balita Usia 12-59 bulan di Banten. Vol 03. No 02. (online) https://www.researchgate.net/publicat ion/339505155_Perilaku_higiene_da n_sanitasi_meningkatkan_risiko_keja dian_stunting_balita_usia_12-59_bulan_di_Banten

Elysa Yutik. 2014. Hubungan Tingkat Pengetahuan dan Perilaku Tentang Higiene dan Sanitasi Makanan di Sekolah Bonagung I Kecamatan Tanon Kabupaten Sragen. Surakarta. (online). https://docplayer.info/75962137- Elysa-yutik-hidayati-j.html. Diakses 5 Januari 2020

Erna Kusumawati, Setyowati R, Hesti Permata S. 2015. Model Pengendalian Faktor Risiko Stunting pada Anak Usia di Bawah Tiga Tahun. Vol 9. No 3. (online). https://media.neliti.com/media/public ations/39896-ID-model- pengendalian-faktor-risikostunting- pada-anak-bawah-tiga-tahun.pdf.Diakses 5 Januari 2020

Evi Nur Rahmawati. 2016. Hubungan Antara Kelengkapan Informasi Medis Dengan Keakuratan Kode Diagnosis Tuberkulosis Pada Dokumen Rekam Medis Rawat Inap Di Rumah Sakit Umum Daerah

Fahmi Hafid. 2015. Faktor Risiko Stunting Usia 6-23 bulan di Kecamatan Bontoramba Kabupaten Jeneponto. Makassar. https://media.neliti.com/media/public ations/213010-faktor-risikostunting- usia-6-23-bulan-d.pdf.(Online). Diakses 4 Januari 2020

Fahmi Hafid. 2017. Efek Program SBABS Terhadap Pencegahan Stunting Anak Baduta di Kabupaten

Palu.(online)https://scholar.google.co.id/citations?user=6IAhvNgAAAAJ\&hl=id\#d=gs_md cita- 
Jurnal Sulolipu : Media Komunikasi Sivitas Akademika dan Masyarakat

Vol. 21 No.12021

e-issn: 2622-6960, p-issn : 0854-624X

d\&u=\%2Fcitations\%3Fview_op\%3Dview_citation\%26hl\%3Did\%26user\%3D6IAhvNgAAA AJ\%26citation_for_view\%3D̄6lAhvNgAAAAAJ3AqjMa kFHDy7sC\%26tzom\%3D-420.

Diakses 5 Januari 2020

Farah Okky Aridiyah, Ninna Rohmawati, Mury Ririanti. 2015. Faktor-Faktor yang Mempengaruhi Kejadian Stunting pada Anak Balita di Wilayah Pedesaan dan Perkotaan. Vol 3. No 1.

Fery Firmasnyah. 2019. Warta Kesmas Kementerian Kesehatan Republik Indonesia.

Gambaran Umum Proyek Kesehatan Dan Gizi Berbasis Masyarakat (PKGBM) Untuk Mencegah Stunting.

Gladys Apriluana, Sandra Fikawati. 2018. Analisis Faktor-Faktor Risiko terhadap Kejadian Stunting pada Balita (0-59 Bulan) di Negara Berkembang dan Asia Tenggara. Vol 28. No 4. DOI:_ https://doi.org/10.22435/mpk.v28i4.4_ 72. https://ejournal2.litbang.kemkes.go.id /index.php/mpk/article/view/472

Indah Budiastutik. 2019. Faktor Risiko Stunting pada Anak di Negara Berkembang. Semarang. Doi: 10.2473/amnt.v3i3.2019.122-129.(online). https://e-

journal.unair.ac.id/AMNT/article/vie w/14301. Diakses 5 Januari 2020

Ircham Faozy. 2017. Perilaku Hidup Bersih dan Sehat Siswa Kelas VII SMP Negeri 1 Bumijaya Kabupaten

Tegal.Yogyakarta.(online).http://journal.student.uny.ac.id/ojs/index.php/pjkr/article/view/67 27. Diakses 5 Januari 2020

Jackson dan Calder. 2004. Undernutrition, infection and immune function. DOI: 10.1079/095442200108728981.(online).https://www.researchgate.net/search/publication? q=mann\%2Bdan\%2Btrusswel\%2B2020\&page=2. Diakses 6 Januari 2020

Kementerian Kesehatan RI. 2014. Peraturan Menteri Kesehatan Republik Indonesia Nomor 3 Tentang Sanitasi Total Berbasis Masyarakat.

Kementerian Desa. Pembangunan Derah Tertinggal dan Transmigrasi. 2017. Buku Saku Desa Dalam Penanganan Stunting.

Kementerian Kesehatan RI. 2018. Pemciuan STBM, Strategi Perubahan Perilaku Dalam Pencegahan Stunting.

Kementerian Kesehatan RI. 2018. Strategi Komunikasi Perubahan Perilaku Dalam Percepatan Pencegahan Stunting.

Kementerian Keuangan. 2018. Penanganan Stunting Terpadu.

Kementerian Kesehatan RI. 2018. Hasil Utama RisKesDas. (online).https://www.depkes.go.id/resources/download/info-terkini/hasil-riskesdas2018.pdf. Diakses 4 Januari 2020

MariatulFadilah.2019. Bonus Of Demography as an Opportunity to Build Indonesian's Welfare (Through the Role of Doctors in Primary Care in the STBM Program for Dercasing the Prevalence of Stunting). Palembang. (online). https://jurnal.ugm.ac.id/rpcpe/article/ view/50205. Diakses 5 Januari 2020

Moh. Fajar Nugraha. 2015. Dampak Program Sanitasi Total Berbasis Masyarakat (STBM) Pilar Pertama di Desa Gucialit Kecamatan Gucialit Kabupaten Lumajang. Vol 3. No 2. Lumajang. (online). http://www.journal.unair.ac.id/downl oad-fullpapers- kmp62b069aeb2full.pdf. Diakses 5 Januari 2020

Nasrul, Hafmid Hafid, A. Razak Thaha, Suriah. 2015. Faktor Risiko Stunting Usia 6-23 Bulan di Kecamatan Bontoramba Kabupaten Jeneponto. (online) http://journal.unhas.ac.id/index.php/ mkmi/article/view/518

POB Pamsimas. 2019. POB Pembangunan Air Minum Dan Sanitasi Sebagai Upaya Pencegahan Stunting.

Siti Nur Ramdaniati, Dian Nastiti. 2019. Hubungan Karakteristik Balita, Pengetahuan Ibu dan Sanitasi Terhadap Kejadian Stunting pada Balita d Kecamatan Labuan Kabupaten Pandeglang. Vol 7. No 2. (online) http://ejournal.uika- bogor.ac.id/index.php/Hearty/article/ view/2877

World Health Organization.2013. CHILDHOOD STUNTING: Challenges and Opportunities. Report of a webcast colloquium on the operational issues around setting and implementing national stunting

reduction agendas.(Online).https://apps.who.int/iris/bitstream/handle/10665/107026/ WHO_NMH_NHD_GRS_14.1_eng.pdf;jsessionid=5D264466C528E2C730B7469B3C40C COB? sequence $=1$. Diakses 5 Januari 2020 
Jurnal Sulolipu : Media Komunikasi Sivitas Akademika dan Masyarakat

Vol. 21 No.12021

e-issn: 2622-6960, p-issn : 0854-624X

Yuliani Soeracmad, Muhammad Ikhtiar, Agus Bintara S. 2019. Hubungan Sanitasi Lingkungan Rumah Tangga Dengan Kejadian Stunting pada Anak Balita di Puskesmas Wonomulyo Kabupaten Polewali Mandar. Vol 5. No 2.

(online) https://www.researchgate.net/publicat ion/338192037_Hubungan_Sanitasi_Lingkungan_Rumah_Tangga_Dengan_Kejadian_St unting_Pada_Anak_Ba bupaten_polewali_Mandar_Tahun_2019 lita_Di_Puskesmas_Wonomulyo_Ka

Zairinayanti, Rio Purnama. 2019. Hūbungan Hygiene dan Sanitasi Lingkungan dengan Kejadian Stunting Pada Balita. Vol 10. No 1. (online) http://jurnal.stikes-aisyiyahpalembang.ac.id/index.php/Kep/articl e/view/186

Zul Fikar Ahmad, Siti Surya Indah Nurdin. 2019. Faktor Lingkungan dan Perilaku Orang Tua pada Balita Stunting di Kabupaten Gorontalo. Vol 4. No http://www.ejournal- aipkema.or.id/aipkema/index.php/jrki/article/view/57

2.(online) 